\title{
Competitiveness of broiler in Tondano Utara district, regency of minahasa in north Sulawesi province, Indonesia
}

\author{
Erwin Wantasen ${ }^{1, *}$, Jein Rini Leke ${ }^{2}$, and Florencia Nery Sompie ${ }^{3}$ \\ ${ }^{1}$ Department of Socio-Economic, Faculty of Animal Husbandry, Sam Ratulangi University, \\ Jalan Kampus Manado, 95115-Indonesia \\ ${ }^{2}$ Department of Animal Production, Faculty of Animal Husbandry, Sam Ratulangi University, \\ Jalan Kampus Manado, 95115-Indonesia \\ ${ }^{3}$ Department of Animal Nutrition, Faculty of Animal Husbandry, Sam Ratulangi University, \\ Jalan Kampus Manado, 95115-Indonesia
}

\begin{abstract}
The research aims to analyze competitiveness of broiler in District of Tondano Utara, Regency of Minahasa. Sampling technique utilized was saturated sampling (census method) by taking all existing samples, containing of 68 samples of broiler in the region of District of Tondano Utara. Further, data analysis employed Policy Analysis Matrix (PAM). The analysis finding shows that PCR (Private Cost Ratio) valuewas less than $(<) 1$, which was 0.65 . This means that business system of broiler cultivated by breeders had competitive advantage. Breeder was able to compete with broiler business in other regions, instead of enabling to finance domestic factor in private price. Husbandry sector had competitive advantage whereas DRCR (Domestic Resources Cost Ratio) value was less than $(<) 1$, representing that advantage obtained by breeder was greater than its social cost of non-tradable input. In broiler's case showed in District of Tondano Utara, DRCR value was less than $(<) 1$, which was 0.96 , depicting that husbandry sector had comparative competitiveness since it could finance its domestic factor related to social cost and it was economically efficient. Therefore it is recommended to encourage market expansion to the export market through the development of broiler chicken meat processing industry in North Sulawesi.
\end{abstract}

\section{Introduction}

Broiler is one of poultry types popularly cultivated by public. A demand of chicken's meat as a supplier of animal protein is increasingly great in number. Currently it has been proven that chicken's meat is the biggest contributor against meat's domestic consumption and production in Indonesia. In 2018, domestic production of chicken's meat was 3,565,495 ton, and consumption demand was 3,047,676 ton, whereas broiler contributed to 51 percent of chicken's meat $[1,2]$.

On the other hand, broiler industry is still dealings with some issues in various sub-sectors

\footnotetext{
* Corresponding author: erwinwantasen@yahoo.co.id
} 
of agribusiness, constituting adverse effects against competitiveness [3, 4]. In upstream subsector, issue related to feed procurement becomes significantly the main issue. Most of feed materials still depends on import, such as import of corn reaching up 40-50 percent; soybean residue of 95 percent; fish flour of 90-92 percent; bone flour and vitamin/feed additive about nearly 100 percent of import [5]. Corn is primary component of broiler's feed. Any country having a higher competitiveness heavily depends on corn's domestic supply [6]. This dependency against imported corn has definitely adverse effect for Indonesia since feed supply is decreasing due to competitive issue with food and fuel. This circumstance causes increasing feed price, whereas allocation for feed cost is the biggest, calculating around 6070 percent of production cost $[6,7]$. The more increasing the feed price, the more improving the production cost of broiler. Proceeding statement becomes contradictive if applied, since Laws Number 18 of 2012 Article 36 section 1 stipulates that any import of husbandry feed shall only be implemented if domestic production of feed may not satisfy and/or it cannot be produced domestically.

Government regulation related to development of broiler industry was started in 1970 through Foreign Investment policy (PMA). Then, the development of broiler seeding from Japan and America was agreed. This policy was subsequently followed by cultivating policy in 1980, regulating limitation of business scale on broiler. The objective of such policy was to provide a wider work opportunity for people, as stipulated in Laws of Husbandry No 18 of 2009.

Regency of Minahasa has 25 Districts, currently optimizing broiler cultivation. The same cultivation condition is in line with economic value of broiler as commodity, improving of chicken's meat production and consumption, and increasing growth of broiler population [7, 8]. Husbandry of broiler is still performed privately, and it is assumed that profit obtained by individual breeders has not been maximal since they have to allocate any cost on their own to obtain production factor, which its price is often fluctuate. Utilization of production factor relatively cheaper will result on efficiency and competitiveness [7]. Some previous researches have analyzed on competitiveness of some commodities, such as estate, food plant, profit, efficiency and feasibility and competitiveness of broiler by partnership design [8-12], yet there is no study concerning on competitiveness of broiler husbandry under private design in District of Tondano Utara, Regency of Minahasa. Therefore, this research aims to acknowledge the competitiveness of broiler husbandry in District of Tondano Utara, Regency of Minahasa, Indonesia utilizing comparative and competitive advantage approach.

\section{Research method}

\subsection{Site and time of study}

This research was performed on February-March 2020 in District of Tondano Utara, Regency of Minahasa, Province of North Sulawesi. The site of research was conducted purposively by consideration that such location was one of broiler production centers in Regency of Minahasa.

\subsection{Sampling method, data collecting technique, and type of data}

The research's sample was chosen by saturated sampling (census method). It means that sampling method is done if all members of population is used as sample [13]. Total of samples taken in this research was all breeders located in District of Tondano Utara, comprising of 68 breeders performing private business. Research data was obtained by survey with guided interview. Then, data obtained consisted of primary and secondary data. 
Primary data was data obtained directly from sample of breeders, comprising of respondent's identity, total and price of input, total and price of output, capacity of broiler purchasing/slaughtering, purchasing price of broiler, slaughtering and marketing cost, and selling price of broiler's meat (carcass). While, secondary data required was population of broiler, development of input and output price of broiler, development of Rupiah exchange currency, import and export price of broiler's input and output and incoming duty obtained by Service of Agriculture and Husbandry, husbandry company, Service of Commerce, Customs office, Bank Indonesia, PT Pelindo and so forth.

\subsection{Data analysis}

Data analysis technique utilized was PAM (Policy Analysis Matrix) method having been developed by Monke and Pearson. PAM Analysis provides complete information on the impact of Government's policy from a production system. It consist of two parts of accounting equation, first identity is defining profit as the positive difference of cost and revenues and the second one is estimating impact of divergence.[14] Therefore, to know broiler's competitiveness in Regency of Minahasa, comparative and competitive advantages of PAM model were employed, as shown in the following Table 1.

Table 1. Construction of policy analysis matrix (PAM) model

\begin{tabular}{|c|c|c|c|c|}
\hline \multirow[b]{2}{*}{ Indicator } & \multirow[b]{2}{*}{ Revenue } & \multicolumn{2}{|c|}{ Cost } & \multirow[b]{2}{*}{ Profit } \\
\hline & & $\begin{array}{c}\text { Tradable } \\
\text { input }\end{array}$ & Domestic factor & \\
\hline Private price & A & B & $\mathrm{C}$ & $\mathrm{D}$ \\
\hline Social price & E & $\mathrm{F}$ & G & $\mathrm{H}$ \\
\hline Divergence & $\mathrm{I}=\mathrm{A}-\mathrm{E}$ & $\mathrm{J}=\mathrm{B}-\mathrm{F}$ & $\mathrm{K}=\mathrm{C}-\mathrm{G}$ & $\mathrm{L}=\mathrm{D}-\mathrm{H}$ \\
\hline
\end{tabular}

Where,

$A=$ Private revenue is production multiplied with market price (IDR)

$\mathrm{B}=$ Tradable input multiplied with market price (IDR)

$\mathrm{C}=$ Input of domestic factor multiplied with market price (IDR)

$\mathrm{D}=$ Private profit (A- B-C) (IDR)

$\mathrm{E}=$ Social revenue is production multiplied with social price (IDR)

$\mathrm{F}=$ Tradable input multiplied with social price (IDR)

$\mathrm{G}=$ Domestic input is multiplied with social price (IDR)

$\mathrm{H}=$ Social profit (E-F-G) (IDR)

Comparative advantage (Domestic Resource Cost Ratio) $=\mathrm{G} /(\mathrm{E}-\mathrm{F})$

Competitive advantage (Privat Cost Ratio) $=\mathrm{C} /(\mathrm{A}-\mathrm{B})$

Output transfer (OT); I = A-E

Input transfer (IT); J= B-F

Factor Transfer (FT); K= C-G

Net policy transfer $(\mathrm{NT}) ; \mathrm{L}=\mathrm{D}-\mathrm{H}$

Nominal Protection of Coefficient on Input (NPCI) $=\mathrm{B} / \mathrm{F}$

Nominal Protection of Coefficient on Output $(\mathrm{NPCO})=\mathrm{A} / \mathrm{E}$

Effective Protection Coefficient $($ EPC $)=(A-B) /(E-F)$

Profitability Coefficient $(\mathrm{PC})=\mathrm{D} / \mathrm{H}$

Subsidy Ratio to Producers $($ SIDR $)=\mathrm{L} / \mathrm{E}$ 


\section{Finding and discussion}

Indicator of Policy Analysis Matrix (PAM) was based on data obtained from respondents (breeders). Such data consisted on breeder's revenue (output), production cost (tradable input and domestic factor), divided based on private price (actual) and social price (shadowed price). Output and input data in private price were inserted into the first row of PAM, while output and input data of social price were inserted in the second row of PAM. After two rows of PAM were filled up, private profit, social profit, output transfer, input transfer, and net transfer were gained. The analysis result of PAM can be seen in Table 2 below.

In detail, cell in the first row is cell A, breeder's revenue in one period of 35 days totally IDR 294,512,501. It was calculated based on selling price of broiler received by breeder from big trader/partner cooperated with breeder. Further, cell B is cost of tradable input (input traded in international market expensed as much as IDR 4,329,231 for every period of broiler. Cell $\mathrm{C}$ is non-tradable input (non-tradable domestic factor in international market) that had to be expensed by breeder to produce in one period (35 days) of broiler as much as IDR $183,720,819$. Total of tradable and non-tradable input is total of input in producing within one period (35 days) of broiler in private price. As shown in table 2 the sum of input

Table 2. Policy analysis matrix of broiler farming/8000 broilers

\begin{tabular}{|l|c|c|r|r|}
\hline Component & Revenue (IDR) & $\begin{array}{c}\text { Tradable input } \\
\text { (IDR) }\end{array}$ & $\begin{array}{c}\text { Domestic factor } \\
\text { (IDR) }\end{array}$ & Profit (IDR) \\
\hline Private Price & $294,512,501$ & $4,329,231$ & $183,720,819$ & $106,462,451$ \\
\hline Social Price & $192,801,861$ & $2,286,780$ & $183,720.819$ & $6,794,262$ \\
\hline Divergence & $101,610,640$ & $2,042,351$ & 0 & $99,668,289$ \\
\hline
\end{tabular}

cost became deducing factor of breeders' revenue, so private profit of breeders (as shown in cell D) was IDR 106,462,451. Cell in the second row, which is cell E, is breeders' revenue in one period ( 35 days) of broiler based on selling price received in accordance with similar poultry price in global market, which was IDR 192,801,861. Cell F, which is tradable input expensed for one period ( 35 days) of broiler, was IDR 2,286,780. Cell G, a non-tradable input cost that must be expensed by breeders to produce in one period (35 days) of broiler, was IDR $183,720,819$. Since there was no import performed for non-tradable input in cell G, cost shown in cell $\mathrm{G}$ was similar with cost depicted in cell $\mathrm{C}$. Total of tradable and non-tradable input was total cost of input to produce in one period (35 days) of broiler under social price. Such total became deducing factor of breeders' revenue, so breeders' revenue in social price (as shown in cell H) was IDR 6,794,262. It is indicated that the use of policy analysis matrix, broiler farm in Tondano Utara District was profitable since social and privat profit on input and output of broiler farming were positive. The results of study were parallel with (14-16), meat processing in Borno State, rice farm in India and broiler production in Malaysia was profitable since privat profit and social profit was positive and resources was efficiently utilized by farmers and processors.

\subsection{Analysis of competitive advantage}

Competitive advantage possessed by broiler husbandry can be viewed based on value indicator of Private Profit (PP) and Private Cost Ratio (PCR). The value of PP and PCR in broiler husbandry is displayed in Table 3.

Table 3. Private profit and private cost ratio

\begin{tabular}{|l|rr|}
\hline \multicolumn{1}{|c|}{ Indicator } & Value \\
\hline Private profit (PP) (IDR) & $106,462,451$ \\
\hline Private cost ratio (PCR) & 0.65 \\
\hline
\end{tabular}


In Table 3, Private Profit had positive value of IDR 106,462,451, presenting that profit derived from operating broiler husbandry. According to above detail, broiler husbandry in District of Tondano Utara is feasibly performed since it earns profit to breeders. While, Private Cost Ratio (PCR) is division between input cost of non-tradable private and input cost of tradable private. Husbandry business has competitive advantage if PCR value is less than $(<)$ 1. It means that profit earned by breeders is more than $(>)$ its input cost of nontradable private. This in line with [15], the lesser the PCR value, the more competitive advantage the commodity. Based on Table 3, PCR value was 0.65 , meaning that broiler husbandry performed by breeders had competitive advantage, where breeders were not only able to finance their domestic factor in private price, but also able to compete with broiler husbandries in other regions.

\subsection{Analysis of comparative advantage}

Comparative advantage can be employed to measure business efficiency of husbandry based on economic analysis. Indicator of comparative advantage on husbandry is measured from Social Profit (SP) and Domestic Resource Cost Ratio (DRCR) value. The value of SP and DRCR in broiler husbandry is clearly shown in Table 4.

Table 4. Social profit and domestic resource cost ratio in broiler farming

\begin{tabular}{|l|r|}
\hline \multicolumn{1}{|c|}{ Indicator } & \multicolumn{2}{|c|}{ Value } \\
\hline Social profit (SP) (IDR) & $6,794,262$ \\
\hline Domestic resource cost ratio (DRCR) & 0.96 \\
\hline
\end{tabular}

From Table 4 above, Social Profit had positive value, which was IDR 6,794,262. It, then, shows that broiler husbandry performed was economically profitable (social). The broiler business will still be profitable, even though there is no government policy regulating input or output, such as either subsidy or price protection and Rupiah exchange currency. Further, domestic resource cost ratio (DRCR) is an indicator of ratio assessment between non-tradable input (domestic resource cost) against added value calculated within social price. A commodity has comparative advantage if DRCR value is less than $(<) 1$. This means that profit obtained by breeders is greater than its input cost of non-tradable social. The lesser the value of DRCR, the greater the comparative advantage owned by broiler commodity and it is economically efficient. Broiler husbandry in District of Tondano Utara had its DRCR value of 0.96 , showing that such business had comparative advantage. In short, breeders were able to finance their domestic factor in social price and it had economically efficient. Though, there is no government intervention and subsidy, broiler husbandry has comparative competitiveness and can still survive in perfect market competition. The finding was accordance with [16] who declared broiler farm in Malaysia has DRCR value less the 1, means broiler industry was efficient.

\subsection{Analysis of Government Policy against Input}

Input policy indicates type of policy stipulated by government and its impact on broiler husbandry in District of Tondano Utara (as shown in Table 5). Input Transfer (IT) value in broiler showed positive value, which was IDR 2,042,351. This figure depicts that there was no government policy in tradable input, so breeders suffered from loss since they, privately, financed tradable input price in the domestic market which was larger than tradable input price in international market.Moreover, Nominal Protection Coefficient Input (NPCI) is ratio to measure IT. This ratio displays how wide is the gap between domestic price of tradable input price and social price. If NPCI is more than $(>) 1$, it means that domestic input cost is 
higher than global input cost. In contrary, if NPCI is lesser than $(<) 1$, it means that domestic input cost is lower than global input cost. From this research, NPCI value obtained was more than $(>) 1$, which was 1.88 . Even though there was no government intervention, the finding of this research showed that NPCI value was 1.88. Thus, government is able to rise tradable input price in domestic market. The findings was in line with [17] who mentioned that domestic input price of broiler was higher than global input cost eventhough there was no government intervention.

Table 5. Indicator of government policy in broiler farming

\begin{tabular}{|l|r|}
\hline \multicolumn{1}{|c|}{ Indicator } & \multicolumn{1}{|c|}{ Value } \\
\hline Input transfer (IT) (IDR) & $2,042,351$ \\
\hline Nominal protection coefficient on input (NPCI) & 1.88 \\
\hline Transfer factor (TF) & 0 \\
\hline
\end{tabular}

Divergence can influence non-tradable input price, so it causes non-tradable private price is different from its social price, and it results on Transfer Factor (TF). In addition, divergence value of non-tradable price can be positive (taxes or resource transfer from husbandry system are applied) or negative (subsidy or resource transfer into husbandry system are applied). In this research, Transfer Factor of broiler husbandry was 0 (zero), meaning that there was no government policy in non-tradable input used by breeders. It can be seen that private price of non-tradable input paid by breeders was similar with its social price [18]

\subsection{Analysis of government policy against output}

Policy against output was analyzed with Output Transfer OT) and Nominal ProtectionCoefficient on Output (NPCO).Below, Table 6 demonstrates that Transfer Output (OT) value was positive, indicating that there was subsidy or resource transfer supplementing profit of farming system. While, OT value was negative presenting that there was tax or resource transfer deducing profit of husbandry system. In domestic market, output price of broiler was lower than output price in international market, viewed from Output Transfer value shown in the Table 6 which was IDR 101,610,640. This means that private revenue of breeders was higher than determined revenue if market was not distorted by output price of broiler, since there was Output Transfer from producer to consumers, which was IDR $101,610,640$.

Table 6. Indicator of Government policy against output of broiler farming

\begin{tabular}{|l|r|}
\hline Indicator & Value \\
\hline Transfer output (OT) (IDR) & $101,610,640$ \\
\hline Nominal protection coefficient on output (NPCO) & 1.53 \\
\hline
\end{tabular}

Nominal Protection Coefficient on Output (NPCO) is ratio to measure Output Transfer (OT). This ratio shows how wide the gap between private price and social price is. If NPCO is larger than $(>) 1$, it means that domestic price is higher than import or export price, and farming system receives protection. Contrastingly, if NPCO is smaller than $(<) 1$, domestic output price is smaller than global price. It depicts that domestic price is unprotected. Based on Table 6, Nominal Protection Coefficient on Output (NPCO) of broiler farm was larger than $(>) 1$, which was 1.53 . It states that domestic output price was higher than output of social price. Thus, breeders should obtain incentive from government to improve or maximize their husbandry. This study was in line with [17) that breeders got higher then expected privat sale value because the market is not distorted by broiler meat prices. 


\subsection{Analysis of government policy against input - output}

Analysis of input-output policy was utilized to analyze government policy against both input and output. This policy was analyzed with value of Effective Protection Coefficient (EPC), Net Transfer (NT), Profitability Coefficient (PC) and Subsidy Ratio to Producers (SIDR). Those indicators are showed in following Table 7.

Table 7. Indicator of government policy against input -output on broiler farming

\begin{tabular}{|l|r|}
\hline \multicolumn{1}{|c|}{ Indicator } & \multicolumn{1}{|c|}{ Value } \\
\hline Effective protection coefficient (EPC) & 1.53 \\
\hline Net transfer (NT) (IDR) & $99,668,289^{\prime}$ \\
\hline Profitability coefficient (PC) & 15.67 \\
\hline Subsidy Ratio to Producers & 0.52 \\
\hline
\end{tabular}

The level of Effective Protection (EPC) is ratio comparing added value in the level of domestic price and in the global price. Hence, the objective of EPC is to show some impacts of joint transfer resulted by a policy, either transfer of tradable output or tradable input. If EPC value is more than $(>) 1$, meaning that policy against output price or subsidy against input price has beneficial purpose for breeders to continuously develop their broiler husbandry. In contrary, if EPC value is less than $(<)$ 1, stating that government policy hampers breeders to produce. Based on Table 7, broiler farming in District of Tondano Utara had Effective Protection Coefficient, which was more than $(>) 1$ (1.53). This means that current policy has beneficial impact for breeders. However, at the time of the research, there was no policy stipulated in District of Tondano Utara related to broiler husbandry. Based on analysis, the value was 1.52 , which was more than $(>) 1$. It was profitable for breeders, though no government policy was applied. The relation with EPC discussion is that any condition without any policy currently applied is profitable, but breeders are safer if there is policy applied. Net Transfer (NT) is sum up of all transfer effects, either positive or negative, and revenue or cost. Based on profitability identity, Net Transfer is sum up of OT, IT and FT, while divergence identity, NT is a difference between private and social profit. Positive value of NT demonstrates that there is surplus addition from producers, but, contrastingly, negative value of NT depicts decreasing profit of breeders due to application of government policy. Based on Table 7, Net Transfer value was positive, which was IDR 99,668,189. This presents that there was economic incentive to improve broiler production. It was seen from profit obtained by breeder when government policy applied was higher than loss, where there was no government policy. Profitability Coefficient (PC) aims to measure effect from all transfers against private profit. This coefficient is similar with ratio between private profit and social profit calculated with similar data by NT calculation. PC value is less than $(<) 1$, meaning that profit's revenue is lower than determined profit obtained in social price. In contrast, PC value is more than $(>) 1$, depicting that breeders' profit is higher than profit in social price. Profitability Coefficient (PC) value in broiler husbandry was 15.67 , meaning that profit received by breeders was higher than determined profit obtained in social price. Without government policy applied, breeders' profit is higher than expected profit obtained by breeders (based on social price). Subsidy Ratio to Producers (SRP) is ratio used to measure all transfer impacts. This ratio shows how much revenue of increasing or decreasing system due to transfer influence. Negative value of SRP displays that government policy applied results breeders to expense production cost against input, which is higher than its balancing cost. Conversely, positive value of SRP depicts that government policy applied causes breeders expensing lower production cost against input. From above Table 6, broiler husbandry had positive value of SRP, which was 0.52 . This result was different from other researches regarding on corn agriculture where farmers had to pay higher input cost than global price [18], resulting on negative value of NT and SRP in rainy season Overall, there 
are 2 impacts due to application of government policy.This application concerns on subsidy against tradable and non-tradable input, beneficially profitable for breeders since it reduces production cost. The latter policy is distortion of output price giving adverse effect for breeders since it reduces breeders' profit This was in line with [16-20] but different with $[21,22]$, government policy on input and output of broiler farm was in positive value means that current policy has beneficial impact for breeders. Although there was no policy stipulated in research area but breeders were able to compete with broiler farming in other regions since them able to finance domestic factors in social price.

\section{Conclusion}

Based on the findings of the study conducted, it has been proven that broiler husbandry in District of Tondano Utara had competitiveness since Private Cost Ratio (PCR) value was less than $(<) 1$, which was 0.65 . It means that husbandry system of broiler cultivated by breeders had competitive advantage, having ability to finance its domestic factor in private price and breeders were able to compete with broiler husbandry in other regions. Beside its competitive advantage, Domestic Resources Cost Ratio (DRCR) value of broiler farm in District of Tondano Utara was less than $(<)$ 1, which was 0.96 . It postulates that broiler husbandry cultivated by breeders had comparative advantage, since breeders were able to finance domestic factor in social price and it was economically efficient. The results of this study have implications for the use of domestic factors to save on the use of foreign exchange

So it is recommended to encourage market expansion on smallholder breeders to the export market through the development of broiler chicken meat processing industry in North Sulawesi Province, Indonesia through various government policies such as soft credit, elimination of value added tax (PPn) and ease of licensing.

\section{References}

1. N.D Wahyono, M.M.D Utami, J Phys: Conf ser. 953, 012125 (2018)

2. Y.L Henuk, Khon Kaen Agr.J, 43.Suppl 2:249-253 (2015)

3. 3. I. A. latief, M.I.A. Hassan, Z.Z. Abidin, G. Rezai, J. Sharifuddin, Z. Mohamed, J. Soc. Sci \& Hum, 23, 63- 76 (2015)

4. A.S. Mendes, D.C. Gudoski, A.F. Cargnelutti, E.J. Silva, E.H. Carvalho, G.M. Morello, Brazilian J. Poultry Sci, 16 (1), 113-120 (2014)

5. S. Nurfadillah, D. Rachmina, N. Kusnadi, J. Indonesian. Trop. Anim. Agric, 43 (4), 429-437 (2018)

6. M. Mengesha, Asean. J. Poult. Sci, 6(2), 31-43 (2012)

7. A.Fitriani, H.K. Daryanto, R. Nurmalina, S.H. Susilowati, Int. J. Poult. Sci, 13 (4), 191197 (2014)

8. K. Setiawan, S. Hartono, A. Suryantini, Agritech, 34 (1), 88 - 93 (2014)

9. M. Herawati, D. Haryono, D.A.H. Lestari, Indonesian J. Anim Sci, 4(3), 277-284 (2016)

10. C.O. Emokaro, K.I. Eweka, J. Appl. Sci. Environ. Manage, 19 (4), 627 - 631 (2015)

11. D. Satapathy, A. Sharma, J.K. Paswan, S. Sarkar, T.K. Varun, Indian Farmer, 4(5), 393405 (2017)

12. A.Panov, N. Panova, G. Zvereva, T. Daeva, A. Mozgovoy, A. Beskopilniy, E3S Web of Conferences, 135 (2019) 
13. Sugiyono,.Metode Penelitian Kuantitatif, Kualitatif dan $R \& D$, Alfabeta, Bandung, $2^{\text {nd }}$ ed (2019)

14. A.O. Mamza, K.K. Salman, I.B. Adeoye, J. Agric. Sust, 6 (2), 132-147 (2014)

15. S. Kanaka, M. Chinnadurai, Eur. J. Phys. Agric. Sci, 1, 8-19 (2013)

16. Z.A. Benalywa, M.M. Ismail, M.N. Shamsudin, Z. Yusop, Int.J. Poult. Sci, 17 (10), 459-466 (2018)

17. E.A.A. Elsedig, M.I. Mohd, M.A. Fatimah, Int. Food. Res. J, 22 (1), 116-121 (2015)

18. L.I. Haryanto, Masyhuri, Irham, Agro Ekon, 29 (2), 244-260 (2018)

19. 19. S. Aedah, M.H.B. Djoefrie, G. Suprayitno, Manajemen IKM, 11(2), 173-182 (2016)

20. 20 K.V. Pilusa, A. Belete, V.A Baloi, African J. Agric Res, 16(6), 843-849 (2020)

21. M.A. Sahinli, M.M.A.Kareem, Food. Sci. Nutr. Technol, 3, 3 (2018)

22. S.D. Gupta, Athens J. Bus. Econ, 1 (1). 9-22 (2015) 